\title{
HVMANITAS
}

\section{O Sócrates de Xenofonte}
Autor(es):
Pinheiro, Ana Elias

Publicado por:

Faculdade de Letras da Universidade de Coimbra, Instituto de Estudos Clássicos

URL persistente:

URI:http://hdl.handle.net/10316.2/27930

DOI:

DOI:http://dx.doi.org/10.14195/2183-1718_60_8

Accessed : $\quad$ 26-Apr-2023 11:19:59

A navegação consulta e descarregamento dos títulos inseridos nas Bibliotecas Digitais UC Digitalis, UC Pombalina e UC Impactum, pressupõem a aceitação plena e sem reservas dos Termos e Condições de Uso destas Bibliotecas Digitais, disponíveis em https://digitalis.uc.pt/pt-pt/termos.

Conforme exposto nos referidos Termos e Condições de Uso, o descarregamento de títulos de acesso restrito requer uma licença válida de autorização devendo o utilizador aceder ao(s) documento(s) a partir de um endereço de IP da instituição detentora da supramencionada licença.

Ao utilizador é apenas permitido o descarregamento para uso pessoal, pelo que o emprego do(s) título(s) descarregado(s) para outro fim, designadamente comercial, carece de autorização do respetivo autor ou editor da obra.

Na medida em que todas as obras da UC Digitalis se encontram protegidas pelo Código do Direito de Autor e Direitos Conexos e demais legislação aplicável, toda a cópia, parcial ou total, deste documento, nos casos em que é legalmente admitida, deverá conter ou fazer-se acompanhar por este aviso. 
humanitas

\section{Vol. LX}

IMPRENSA DA UNIVERSIDADE DE COIMBRA

COIMBRA UNIVERSITY PRESS 


\title{
O SÓCRATES DE XENOFONTE
}

\author{
Ana Elias Pinheiro \\ Universidade Católica Portuguesa \\ elias.ana@gmail.com
}

\section{Resumo}

Em 399 a.C., Atenas assistiu a um processo judicial cuja discussão se prolonga até aos nossos dias e que condenou à morte o mais célebre dos filósofos: Sócrates.

A este processo dedicou Xenofonte três obras, Memoráveis, Banquete e Apologia, todas elas marcadas pela parcialidade do discípulo empenhado a todo custo na defesa do mestre, injustamente condenado.

Do retrato que destas obras se exclui, pois, todo e qualquer elemento que pudesse resultar prejudicial à imagem de Sócrates; um Sócrates que não é tanto o Sócrates-filósofo e sim o Sócrates-mestre, familiar e amigo: um Sócrates sem defeitos, o mais pio, mais justo, mais útil, mais contido, mais prudente, mais sabedor, mais apto e eficaz, em suma, o melhor e o mais afortunado dos homens, que os Atenienses condenaram por não terem conseguido entender.

Palavras-chave: Xenofonte, Sócrates.

\section{Abstract}

In 399 B.C. in Athens a judicial process, whose discussion has lasted until the present time, condemned Socrates, the most famous of all philosophers, to death.

To this process Xenophon dedicated three works, Memorabilia, Symposium and Apology, all of them characterized by the partiality of a disciple totally committed to the defense of his master, who had been unfairly condemned.

From the description of these works it is, thus, excluded every element that could be considered harmful to Socrates' image: a Socrates that is not so 
much the philosopher, but instead the master, who is familiar and friendly: a Socrates without defects, the chastest, the fairest, the most helpful, the most reserved, the most prudent, the wiser, the most apt and efficient; in sum, the best and luckiest of all men, whom Athenians condemned because they were unable to understand him.

Keywords: Xenophon, Socrates.

«Entre a caricatura de Aristófanes e o Sócrates enobrecido de Platão existe um homem amável que não pretende dominar pela sua superioridade: Xenofonte não quis pintar o génio e sim o Sócrates de todos os dias, mais acessível e mais próximo dos homens correntes que - Sócrates de Platão.»

(Zaragoza 1993: 300)

Fazer uma análise do retrato de Sócrates implica dizer, em primeiro lugar, que já não andamos à procura do Sócrates histórico. Lembro, a propósito, as palavras de Gray (1998: 25) de que «já não está em causa que Xenofonte tenha sido capaz de entender a metodologia socrática ou a sua doutrina e, sim, a razão pela qual escolheu apresentá-lo do modo como o faz». Julgo, em resposta a esta observação, que, muito provavelmente, Xenofonte não disse, nem em Memoráveis, nem em qualquer outro dos seus escritos socráticos, o que efectivamente sabia sobre Sócrates, mas, sim, o que, desse conhecimento, the interessava transmitir e que se mostrasse em concordância com o propósito que tinha delineado para a obra (Mem. 1.3.1): Como de facto me parece que Sócrates era um bom auxílio para os seus companheiros, quer pelo testemunho do seu comportamento, quer pelo que dizia, vou registar tudo quanto dessas memórias guardo. Deste retrato de um Sócrates sem defeitos tinha de ser excluído, evidentemente, tudo o que pudesse ser polémico.

Tendo em conta, de resto, a observação de Breitenbach (1967: 1772-1773) de que não podemos olhar para as obras socráticas, mesmo as de Xenofonte, como obras históricas, então teremos forçosamente de ver neste Sócrates (como no de Platão, também) algo de 'personagem literária'. Se há determinadas características, de facto, em que os vários testemunhos coincidem e que podemos imputar à figura real do filósofo, a verdade é que a maior parte do que sabemos sobre Sócrates é o que os seus discípulos nos quiseram dizer. E se Sócrates não é figura histórica em Xenofonte, que era historiador, muito menos pois o poderá ser em Platão, que não era historiador, não pretendia sê-lo e mostra até, geralmente, alguma despreo- 
cupação com a precisão, a que hoje chamaríamos histórica, dos seus testemunhos. Um e outro não estavam, com as suas várias obras sobre o filósofo, a construir uma biografia e, sim, de modo mais ou menos assumido, uma apologia. Mesmo nas doutrinas, provavelmente - e parece-me que essa será sempre a posição mais defensável - nenhum dos Sócrates, nem o de Platão, nem o de Xenofonte, poderá corresponder com exactidão ao Sócrates real, porque não é ele quem fala, e, sim, em seu nome, os seus discípulos. Qualquer das doutrinas apresentadas terá contado, sempre, com a interpretação de quem a reproduzia e um e outro, no caso de Platão e Xenofonte, tinham limitações que terão condicionado o modo como transmitiram as ideias do mestre. Poderá dar-se o caso de que Platão tenha tido alguma vantagem, pois estava mais próximo no tempo, enquanto Xenofonte recorda a mensagem do filósofo sob a forma de lembranças, que dão ao seu testemunho um tom mais ligeiro e presumidamente descuidado e, portanto, menos rigoroso; mas Platão trabalhava em termos científicos as doutrinas do mestre, com vista a transmiti-las a outros. A sua é, naturalmente, uma transmissão mais completa, porque mais reflectida, mas, não tem, contudo e forçosamente, que ser mais fiel, porque não deixa de ser indirecta e, sobretudo, interpretativa.

Importante será também termos em conta que os testemunhos que possuímos são, sobretudo, os de defesa. Da acusação, conhecemos apenas informações indirectas ${ }^{1}$, mas parece-me claro que terá existido, em certos

${ }^{1}$ Teria tido particular impacto um panfleto perdido da autoria do sofista

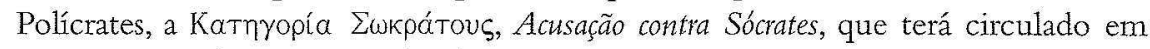
Atenas, nos últimos anos da década de 90 do séc. IV (394 ou 393?), e que pretenderia ser a reprodução do discurso de acusação de Ânito. $\mathrm{O}$ seu teor aproximado conhece-se pela Apologia de Sócrates de Libânio (vide Brickhouse/Smith 2002: 122-132; Calder 2002: 39-219) e insistiria particularmente no desprezo de Sócrates pelas leis e pela constituição democrática. À excepção de Favorino (Memorabilia), os restantes autores antigos datavam este texto da época do processo. Polícrates era provavelmente ateniense e foi contemporâneo de Isócrates (Busíris, 4,

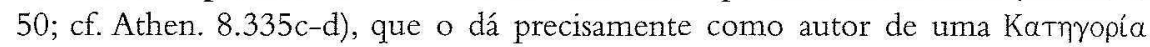
$\Sigma$ ¿крáтouৎ (vide também Quint. Inst. 2.17.4; D.L. 2.39-40; Them. Or. 23; Lib. Ap;

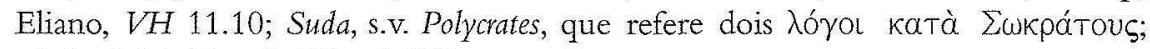
schol. ad Aristidem, 3.480 e 3.320$)$.

Para Giannantoni (2001: 292), não só Xenofonte mas também os outros socráticos, Platão, Ésquines e Antístenes, estariam a responder, com os seus diálogos a estas acusações de Polícrates e não às do processo real. 
sectores da Atenas do século V, um relativo consenso acerca da figura de Sócrates e, porventura, nem sempre favorável: os Atenienses condenaram Sócrates e fizeram-no com acusações similares àquelas de que a Comédia Antiga já fizera eco, cerca de duas décadas antes do processo ${ }^{2}$. Podemos até aceitar, tal como fizeram, quer Platão, quer Xenofonte, que os Atenienses estavam errados; mas se, contudo, quiséssemos, de facto, reconstituir a verdadeira personalidade de Sócrates, ser-nos-ia decerto necessário fazer uso dos traços de carácter que lhe atribuíram os seus opositores.

No caso de Xenofonte, que em particular nos ocupa, será necessário não esquecer que este escritor não é conhecido por retratar com imparcialidade as suas figuras, e, neste caso, poderá ter sido até bastante parcial, porque falava assumidamente em defesa do filósofo; o mesmo acontecia, de resto, nos retratos traçados em discursos forenses que the poderão ter servido de modelo (Calvo Martínez 2004).

A construção de um retrato completo, quanto possível, fisico e moral, de Sócrates, a partir da obra de Xenofonte, precisará de combinar elementos presentes em cada um dos textos que Autor dedicou ao filósofo, os Memoráveis mas também a Apologia e o Banquete.

${ }^{2}$ No final da peça de Aristófanes, o velho Estrepsíades via, precisamente, na destruição da escola (e não sabemos até que ponto do seu mestre; vide, e.g., F. D. Harvey (1981), "Nubes 1493ff: Was Socrates Murdered?”, GRBS 22.4: 339-343) a solução para a perniciosa influência de Sócrates sobre aqueles que frequentavam o seu ensino.

Curiosamente, sendo este o único testemunho redigido ainda em vida do filósofo, foi aquele também que, desde a Antiguidade, mais depressa foi rejeitado. Não foi, contudo, Aristófanes o único comediógrafo a centrar na figura de Sócrates a sátira aos mestres da Atenas do seu tempo. Em 423, ano em que as Nivens ficaram em terceiro lugar nas Dionísias, o segundo lugar coube ao Cono de Amípsias, dirigido expressamente contra Sócrates, que seria de novo personagem, e em moldes muito semelhantes aos de Aristófanes, dois anos mais tarde, nos Comiloes de Êupolis (vide Bouvier 2000). Será curioso, contudo, verificar que, em 423, a comédia vencedora, a Garrafa, de Cratino, era a única que não contava com a figura de Sócrates na sua galeria de personagens.

Este papel de Sócrates na comédia despertou, de resto, comentários ao longo de toda a Antiguidade, desde aqueles que o encaravam como um recurso literário àqueles que, como Eliano ( $V H$ 2.13), viram em Sócrates, o melhor dos Gregos, alvo de uma calúnia perpetrada por um poeta, Aristófanes, que se deixara corromper por aqueles que queriam condenar o filósofo (vide Bouvier 2000: 430-431). 
O mais antigo retrato fisico de Sócrates, o que fizera Aristófanes em Nuvens (cf. também Av. 1281-1282), satirizava a figura do filósofo, acentuando traços caricaturais como a palide $z^{3}$ e os cabelos compridos ${ }^{4}$, atributos que se assemelhavam àqueles que na pintura dos vasos de finais do séc. V caracterizavam os intelectuais em geral, reflectindo no seu aspecto físico os efeitos do seu ensino (vide Zanker 1995: 32-34, figs. 19 e 20). Desse modo, o poeta cómico condenava os defeitos morais exagerando-lhe os físicos, com os quais se combinavam hábitos bizarros de falta de higiene ou de indumentária (cf. Ar. Nu. 836-837; Pl. Smp. 174a; cf. também Mem. 1. 2. 5) .

${ }^{3}$ Insistentemente Sócrates e aqueles que the frequentam a escola são descritos como amarelentos (vv. 103 e 1112; a mesma ideia nos vv. 184-186, 198-199, 500-504) ou sumidos de cores (v. 120). Vide, a este propósito, D. Leão (1995), "Retrato físico de Sócrates nas Nuvens e em Platão. Breve Apontamento", Humanitas 47: 327-339.

+ Que lembravam, decerto, a simpatia do filósofo e dos seus companheiros por Esparta. Também no passo citado das Aves, o comediógrafo descreve os

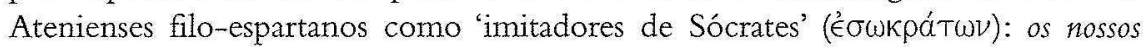
homens estavam todos possuidos por uma laconite: cabelos compridos, famintos, sujos, tipo Sócrates.

${ }^{5}$ Ar. Nu. 836-837: para pouparem dinheiro nenhum deles corta o cabelo, unge o corpo ou vai aos banhos lavar-se. Aristófanes não é o único comediógrafo a ressaltar a bizarria deste comportamento, também Amípsias, no Cono (frg. $9 \mathrm{~K}-\mathrm{A}$ ), acusara Sócrates de ser a perdição dos curtidores por se recusar a usar sapatos. Alguns dos hábitos que o comediógrafo, contudo, the atribui não encontram eco nas obras socráticas, como o gosto pelos espaços interiores, ou a extrema pobreza que fazia com que os discípulos do Pensadouro só pudessem comer quando furtavam alguma coisa. Esses aspectos, sim, seriam aqueles que a figura cómica de Sócrates tomava por sincretismo dos seus colegas de ofício: Querefonte, Antístenes, e outros. Vide, sobre o assunto, F. Souto Delibes (1997), "La figura de Sócrates en la comedia ateniense", in Actas Congreso (1996) Sociedad, Política y Literatura. Comedia Griega Antigua. Salamanca, 339-345.

A referência de Platão, no passo citado do Banquete, é igualmente irónica mas apresentada pela positiva: - Contou-me ele que encontrara Sócrates bem lavado, de sandalias calçadas, o que raramente fazia, e the perguntou onde ia assim todo preparado. Ele respondeu: «Vou jantar a casa do Ágaton. Ontem, com receio da populaça, não fui às cerimónias da sua vitória, de modo que hoje aceitei lá ir. Por isso me pus assim todo bonito.» 
Mas a verdade é que os demais retratos do flósofo não contrariam a caricatura traçada pelo comediógrafo; de facto, no caso de Sócrates, a sabedoria parece que não se fizera acompanhar de beleza física e assim o descreve também Xenofonte, com humor, no Banquete (4. 19, 5; cf. Pl., Smp. 215b): notoriamente feio, de olhos esbugalhados, nariz achatado com narinas arrebitadas, lábios grossos, parecido com um sileno, mas que vê na sua fealdade vantagens que the permitem competir com os mais belos (Critobulo, em Xenofonte; mas também com Alcibíades, no outro Banquete, o de Platão); os olhos esbugalhados permitem-lhe ver em todas as direcçôes, com as narinas arrebitadas pode captar cheiros vindos de todos os lados, o nariz achatado não constitui um obstáculo à visão, os lábios grossos dão melhores beijos, os Silenos são feios mas filhos de deusas.

Parecido com um Sileno, também, é retratado na mais antiga das estátuas que conhecemos (datada talvez da época imediatamente a seguir à sua morte; vide Zanker 1995: 35, fig. 21; 37, fig. 23; 58), de que só se conserva a cabeça, mas cujo traço sugere a possibilidade de um corpo baixo e roliço, porventura à imitação também de algumas das representações conhecidas dos Silenos, embora com certa amenização de traços.

À luz do que eram os padrões clássicos da kalokagathia, as feições grosseiras de Sócrates estariam muito próximas das de um homem de baixa condição (cf. Cic., Tusc. 4. 81). Assim, tal como o pensamento de Sócrates parece ter constituído um corte com a filosofia anterior, também o seu retrato poderá ter correspondido a uma ruptura com a ideia prevalecente na cultura grega desde os tempos heróicos de que a kalokagathia (como o próprio termo sugeria) era apanágio apenas dos belos, idealizando a beleza física como reflexo da beleza moral. A figura de Sócrates concretiza o oposto desta ideia, a mais bela e sábia das almas num corpo feio, mas cujos traços se revestem de uma utilidade muito maior do que se fossem belos.

De igual modo, a comparação estabelecida com os Silenos poderá não advir de uma simples bizarria ou constatação de fealdade por parte dos seus contemporâneos; Sócrates não seria o único Ateniense feio do seu tempo e em nenhum outro esta característica parece ter despertado tanto interesse. É, de resto, o próprio Sócrates que assim se identifica (pelo menos, é a ele que os discípulos o atribuem), parecendo encontrar nesse aspecto algum motivo de orgulho: na tradição mitológica, os Silenos, pese embora a sua fealdade, eram vistos como seres intelectualmente dotados, a 
quem fora confiada a educação de crianças divinas ou heróicas, como fora o caso de Dioniso ${ }^{\text {. }}$.

Uma modificação estética da representação escultórica de Sócrates poderá ter a ver com a posterior reabilitação da imagem, porventura, não demasiado positiva que tivera em vida e que, a avaliar pelo empenho dos seus discípulos na sua defesa, terá tido ainda nas décadas posteriores à sua morte; assim, se é certo que não era possível corrigir o que parecia óbvio - que Sócrates fora um homem feio -, as estátuas de épocas seguintes dotam-no pelo menos de uma postura corporal mais digna do homem cujas superiores qualidades morais e intelectuais passam a ser reconhecidas. Assim o diz Diógenes Laércio, em 2. 43, ao referir a estátua que, arrependidos pela actuação de 399, os Atenienses encomendaram a Lisipo, e que poderá ter estado na base das imagens conhecidas desta segunda fase de representação do filósofo (in Zanker 1995: 59, fig. 33; 62, fig. 35).

Os testemunhos de Platão e de Xenofonte coincidem também com o de Aristófanes, na atribuição a Sócrates de certo tipo de comportamentos, como o pouco interesse por banhos e calçado, mas também de certos traços de conduta moral que abonariam, esses, sim, a favor do filósofo, como a sua coragem e persistência e também a sua contenção, elemento muito vincado no retrato moral que dele traça Xenofonte, a quem parece interessar muito mais a faceta de Sócrates-mestre, familiar e amigo, do que a de Sócrates-filósofo.

Para a acusação anónima de Memoráveis, nas suas múltiplas vozes, Sócrates é aquele que desprezou os deuses da cidade, substituindo-os por

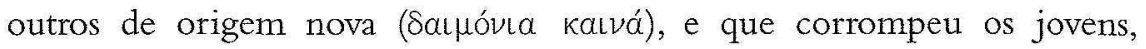
afastando-os dos seus deveres familiares e das orientações da constituição democrática, fazendo depender as suas relações familiares e de amizade de um interesse utilitário; é também alguém que se dedicava aos estudos cosmogónicos e que usava a literatura para fins subversivos. Para Xenofonte, que o conheceu e com ele conviveu (Mem. 4.1.1), a imagem do filósofo é precisamente a inversa. Sócrates é, em primeiro lugar, um homem sem segredos nem comportamentos misteriosos: que vive às claras, nos passeios públicos, nos ginásios, na ágora, em sítios onde pode ver muita gente, falar com muita gente, ser ouvido por muita gente (Mem.

${ }^{6}$ Vide Zanker 1995: 38: «a conotação com o mestre sábio era uma conotação óbvia no retrato de Sócrates-Sileno». 
1. 1. $2 ; 1.1 .10)^{7}$. Este testemunho insistente de Platão e Xenofonte (embora, no caso de Memoráveis, os espaços, e também o tempo, raramente sejam precisados) sobre a predilecção de Sócrates por espaços públicos contrasta claramente com o testemunho de Aristófanes, cujo Sócrates


facto que se reflecte na palidez que todos eles apresentam. Platão e Xenofonte poderiam, ainda (Dorion 2000: 59, n. 28), estar a responder a Polícrates que, de acordo com o testemunho de Libânio (Ap. 114), teria acusado Sócrates de, em segredo, ministrar aos seus discípulos ensinamentos imorais.

Mas Sócrates é, também, um homem inspirado por uma divindade, o seu célebre Saunóvov, que guia não só a sua conduta mas também a conduta daqueles que o acompanham; neste comportamento, não consegue ver Xenofonte nada de estranho ou anormal: Sócrates, como qualquer outro Ateniense do seu tempo, segue auspícios, oráculos, avisos divinos, faz sacrifícios (Mem. 1. 1.3). É, pois, um crente igual aos outros e que tenta converter os seus companheiros, como é explícito no caso de Aristodemo (Mem. 1. 4. 2); a única diferença está, decerto, na marca específica que o historiador, enquanto discípulo, atribui ao carácter do filósofo: Sócrates

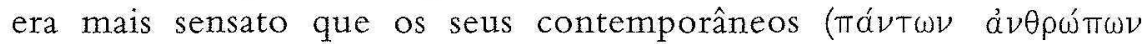

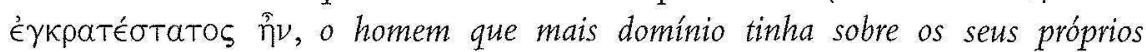
desejos, Mem. 1. 2. 1), e é esse traço que porventura marcará a diferença no seu comportamento ao longo de todos os episódios recontados na obra ${ }^{8}$. Esta sensatez reveste-se também de um certo pragmatismo: se há coisas que os deuses colocaram ao alcance da inteligência humana (Mem. 1. 1. 9), não fará qualquer sentido consultar os deuses para as resolver; esse pragmatismo, de resto, não se revela apenas em matérias religiosas mas também na ideia, mais do que uma vez referida, de que não vale a pena perseguir o fundo das ciências para além do que elas podem trazer de útil ao homem (Mem. 4. 7.2-8), assumindo a crítica àqueles que o fazem (Mem. 1. 1. 13-15; 1. 2. 31-32, 4. 7).

${ }^{7}$ Este é o retrato que faz também Platão, cujos diálogos têm habitualmente por cenário um destes espaços; cf. Euthd. 271a, Smp. 223d, Ly. 203a, Euthph. 2.

${ }^{8}$ Esta ideia de que a principal virtude de Sócrates era ajudar os outros através das conversas que estabelecia com eles é testemunhada por outros socráticos, como Ésquines (em Alcibíades e Aspásia). 
Sócrates é claramente alguém em quem Xenofonte viu um mestre mas é também, nas palavras daquele que se entendeu seu discípulo, alguém que em circunstância alguma admitiu que transmitia ensinamentos (Mem. 1. 2. 3), que criticava os que o faziam e sobretudo os que, ao contrário dele, se faziam remunerar por esse ensino (Mem.1.2.6), num testemunho profundamente coincidente com o de Platão.

Xenofonte dá-nos também a imagem de um homem politicamente descomprometido. É certo que se notam muitas vezes as suas simpatias que Xenofonte partilharia - por Esparta (Mem. 3. 5. 15-17), mas a sua atitude crítica em Atenas atinge todas as facções políticas da cidade, desde a oligárquica Tirania dos Trinta, à qual o acusavam de associação através de Crítias (Mem.1.2.12-38), ao sistema democrático no que ele tinha por, porventura, menos justo e de mais radical, como no caso de Trasilo e Erasínides (Mem. 1.2.17-19), mas também no que tinha de pouco técnico ou especializado (Mem. 1. 2. 9; 3. 7. 7).

Este Sócrates não parece, obviamente, ser uma figura de trato fácil, o que poderá explicar muitas das inimizades que the foram atribuídas e que tiveram, em última instância, influência na sua morte. Curiosamente, e sendo certo que a intenção de Platão não seria menos apologética que a de Xenofonte, a verdade é que, no nosso Autor, estes traços se apresentam mais amenizados. Sócrates, de facto, esforça-se bastante por expor os seus opositores ao ridículo, mas esta é uma faceta que é muito mais explorada por Platão, nos diálogos aporéticos, do que por Xenofonte, embora também aconteça nalguns dos episódios de Memoráveis. O Autor prefere dar mais ênfase aos aspectos virtuosos do filósofo do que às suas excentricidades. Contudo, momentos há em que, apesar de ter tentado, digamos que, 'branquear' a personalidade do mestre, despojando-o de eventuais defeitos que pudessem perturbar o seu propósito apologético, não pôde evitar que transparecessem aquelas marcas de carácter onde o leitor mais avisado poderá encontrar o Sócrates de sempre, que gosta de discutir determina-

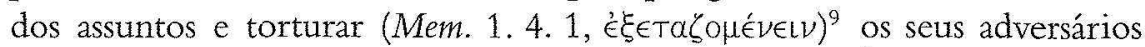
com questões que os levem a admitir a sua ignorância. É ver-dade que, na maior parte dos casos, esse é o Sócrates retratado pela voz dos seus rivais, como em Mernoráveis, 1. 2. 36-37, quando é acusado por Cáricles de estar

${ }^{9}$ O termo utilizado implica precisamente uma exposição ao ridículo (vide Rossetti 2000: 264). 


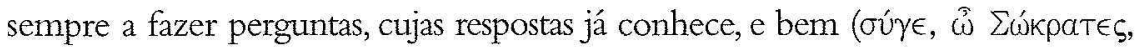

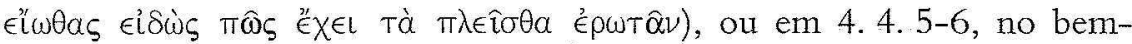
-humorado encontro com Hípias de Élide, que zomba de Sócrates, quando, anos decorridos sobre a última vez que se encontraram, vem surpreendê-lo a dizer as mesmas coisas sobre os mesmos assuntos. Este deverá ter sido, forçosamente, um traço do carácter do Sócrates histórico porque nele insistem todos os seus discípulos (vide Rossetti 2000), embora, sendo certo que a culpa não pertence apenas a Sócrates; os seus interlocutores têm também habitualmente um handicapt: subvalorizam a importância das questões colocadas por Sócrates e, como tal, acabam sem saber o que dizer e nem sequer parecem, muitas vezes, suspeitar quais as verdadeiras intenções de Sócrates. E, tanto Platão, como Xenofonte, fazem questão de que o público tenha consciência deste embaraço, por vezes, mesmo antes de que o visado o perceba. E quando Hípias (Mem. 4. 4. 9-10) o acusa de fazer perguntas e refutar as respostas dos outros sem nunca dar a sua própria opinião, Sócrates responde (como na Apologia) que os seus actos confirmam o seu pensamento: não necessita definir justiça porque nunca prestou falsos testemunhos, nunca denunciou ninguém, nunca provocou a discórdia entre amigos ou na cidade, nunca praticou qualquer acto injusto; e Hípias dá-lhe razão.

Mas, mesmo quando é o próprio Xenofonte a deixar escapar comentários como estes (cf. Mem. 1. 4. 1, 4. 2. 2, 4.2.6, 4.2. 40) é visível que o faz em sentido positivo, e este retrato em nada se torna incompatível como o traço principal, o da moderação, que o discípulo the confere, porque the é atribuída a mesma boa finalidade de conduzir os outros ao seu próprio conhecimento. Este traço da moderação é, sem dúvida, aquele que melhor assenta a Sócrates: o homem a quem pouco basta (1.3. 5-6),

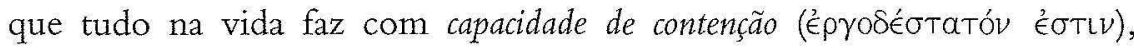
desde a política às relações pessoais, como é possível verificar na sua posição contra o relacionamento sexual, sobretudo entre homens adultos e rapazitos (cf. 1. 3. 9, 1.3.14) ${ }^{10}$.

Poderá ser legítimo questionar se, de facto, Xenofonte terá visto Sócrates deste modo; se era essa a recordação que guardara do tempo de

${ }^{10}$ Não parece, contudo, como se lê, no Banquete $(2.3 ; 8.3 ; 9.7)$ ou no Económico que as condene entre marido e mulher. 
convivência com o filósofo ou se este retrato era ditado apenas pela necessidade que manifestava de o redimir. Esta resposta, como outras, também não está totalmente ao nosso alcance, mas parece-me claro que Xenofonte pretendeu mostrar que assim era o Sócrates que ele conhecera ( $\mathrm{Mem}$.

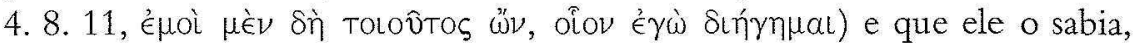
precisamente porque o conhecera ${ }^{11}$, e também o sabiam todos quantos

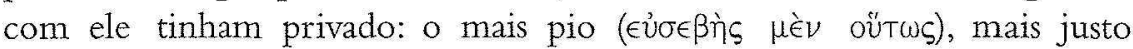

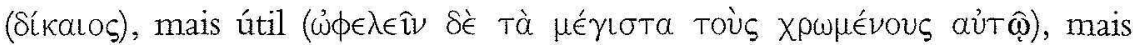

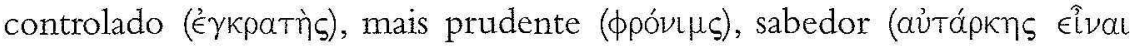

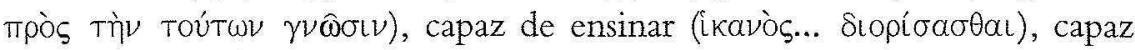



11 Os episódios que chegaram até nós da convivência de Xenofonte com Sócrates são poucos: o seu próprio testemunho, na Anábase (3. 1. 5), e o de Diógenes Laércio (2. 48). Discute-se ainda que Xenofonte tenha efectivamente pertencido aos círculos socráticos porque o único, de entre os reconhecidos como seguidores de Sócrates, que o cita é Ésquines, no diálogo Aspásia (apud Cic. Inv. 1. 31, 51-53). Mas, ignorarem-se uns aos outros parece ter sido um comportamento habitual entre os Socráticos: Platão só de passagem refere Antístenes (Phd. 59b), Ésquines (Ap. 33e) ou Aristipo (Phd. 59b) e ignora Xenofonte completamente; este, por sua vez, também o refere uma única vez (Mem. 3.6.1), não o mencionando, por exemplo, quando, em Memoráveis 1.2.48, enumera os mais importantes seguidores de Sócrates: Críton, Querefonte, Querécrates, Hermógenes, Símias, Cebes e Fedondas; desta lista não consta Platão, mas, na verdade, também não constam Antístenes, nem Ésquines, nem Aristipo, que não consta sequer da lista de Panécio em D.L. 2. 64, 2. 85.

Também Breitenbach (1967: 1770) desvaloriza este facto, não achando improvável que Xenofonte tenha conhecido Sócrates tão bem como Platão: uma relação estabelecida talvez entre os anos de 409-401 teria dado a Xenofonte o tempo suficiente para ter sido influenciado pelo mestre. E na realidade, Xenofonte é até bem mais incisivo que Platão ao afirmar que frequentou o círculo socrático. Platão só uma vez (Ap.34a) se apresenta como espectador dos seus diálogos (embora faça questão de afirmar quando não está presente) e também nunca faz, ao contrário de Xenofonte, apreciações sobre o pensamento socrático nem emite opiniões ao contrário de Sócrates (Bruell 1994: vii).

A Antiguidade, de resto, nunca questionou o relacionamento entre Sócrates e o escritor e, segundo Diógenes Laércio (2.64), Panécio incluíra os diálogos de Xenofonte na lista dos $\Sigma \omega \kappa p a t ı k o l ~ \Lambda o ́ \gamma o t ~ c o n s i d e r a d o s ~ a ̉ \lambda \eta \theta \in \hat{\imath} \varsigma$, dignos de crédito. 


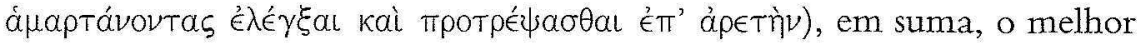

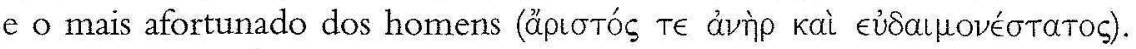
Com esta súmula das qualidades de Sócrates, Xenofonte termina a sua obra maior, recorrendo à mesma fórmula utilizada na Apologia (34): o público, que o ouviu demonstrar as qualidades do filósofo, deverá agora compará-lo a outros e julgar se poderia ter existido homem melhor.

Estas palavras, numa e noutra obra, são sem dúvida a melhor síntese de tudo quanto Xenofonte quis mostrar sobre Sócrates.

\section{Bibliografia}

M. Banini et L.-A. Dorion (2000), Xénophon. Mémorables. Livre I. Paris.

D. Bouvier (2000), "Platon et les poètes comiques: peut-on rire de la mort de Socrate?", in M.-L. Desclos (dir.), Le Rire des Grecs. Grenoble, 425-440.

H. R. Breitenbach (1967), "Xenophon von Athen", RE, IX A 2, 1569-2052.

Th. Brickhouse and N. D. Smith (2002), The Trial and Execution of Socrates. Sources and Controversies. Oxford.

Chr. Bruell (1994), "Xenophon and his Socrates", in Amy L. Bonnette, Xenophon. Memorabilia. New York, vii-xxii.

W. M. Calder, ed. (2002), The Unknown Socrates Translations, With Introductions and Notes, of Four Important Documents in the Late Antique Reception of Socrates the Athenian. Illinois.

J. L. Calvo Martínez (2004), "Oratoria y biografia. El retrato de Alcibíades en Lisias e Isócrates", in A. Pérez Jiménez, J. Ribeiro Ferreira e M.C. Fialho (eds.), O retrato literário e a biografia como estratégia de teorização política. Coimbra-Málaga, 37-48.

A.H. CHroust (1957), Socrates. Man and myth. The two Socratic apologies of Xenophon. London.

R.G. EDmonds (2000), "Socrates the Beautiful: Role Reversal and Midwifery in Plato's Symposium", TAPhA 130:261-285.

G. Giannantoni (2001), "L'Alcibiade d'Eschine et la littérature socratique sur Alcibiade", in G. Romeyer-Dherbey et J.-B. Gourinat, (eds.), Socrate et les Socratiques. Paris, 289-307

V. GRAY (1998), The framing of Socrates: the literary interpretation of Xenophon's Memorabilia. Stuttgart. 
L. RossetTi (2000), "La ridicule comme arme entre les mains de Socrate et de ses élèves”, in M.-L. Desclos (dir.), Le Rire des Grecs. Grenoble, 253-268.

P. ZANKER (1995), The Mask of Socrates: The Image of the Intellectual in Antiquity. Berkley-Los Angeles-Oxford.

J. Zaragoza (1993), Jenofonte. Recuerdos de Sócrates. Económico. Banquete. Apología de Sócrates. Madrid. 